\title{
THE INFLUENCE OF NEGATIVE TRANSFER ON STUDENTS' ABILITY TO USE GOOD ENGLISH
}

\author{
Rana Abid Thyab \\ Ms., Tikrit university/College of Education for Women, Iraq, ranajazaa2019@gmail.com
}

\begin{abstract}
Native speakers of Arabic face a number of problems in their attempt to acquire the English language. One of these problems is found in their attempt to use determiners, such as articles, quantifiers, adjectival possessive pronouns, and so forth. The most common reason of mistake, error and failure in appropriately learning and communicating in English as a second/foreign language is due to what is known as mothertongue interference and negative transfer from one's native language, especially by L1 Arabic learners.

The Arabic language has a structural system which, in many features, is different from that in English. Therefore, mistakes and errors occur when students refer back to their native language (Arabic) when communicating in the second/foreign language (English). The aim of this paper is to pinpoint the influence of Arabic mother-tongue interference and negative transfer from the students' first language on proper command of English, especially regarding the above mentioned structural features. This is done by illustrating how the differences between the Arabic and English languages in concern to the certain grammatical and structural features cause L1 Arabic learners of English as a second/foreign language to make repeatable mistakes and errors in English.

Given the fact that determiners, articles, as well as prepositions, and other below mentioned structural features are one of the most frequent words used in the English language, this paper has, therefore, aimed to discuss such an important matter.
\end{abstract}

Keywords: Negative transfer, first language, interference

\section{INTRODUCTION}

Learners of English as a second/ foreign language with an Arabic mother-tongue encounter shared difficulties when it comes to using English articles, adjectival possessive pronouns quantifiers, prepositions, etc. Because of the nature of the structural systems in both Arabic and English, and due to the differences between their features and rules of appliance negative transfer from the mother-tongue of native Arabic students may occur. As a result, negative transfer and mother-tongue inference strongly limit students' learning abilities and proper command of the target language (English). Learners of English as a second/foreign language come upon many problems which many of them is due to mother-tongue interference and negative transfer from the native language. Negative transfer is the negative effect of the learners' native language on second/foreign language learning. Therefore, it is found that $L 1$ Arabic students and learners of the English language, especially when it comes to using certain English language points, such as common-used structural features, face interference and negative transfer from their first language (Arabic). This is mostly found when attempting to learn to properly use determiners, and prepositions in ESL/EFL (English as a second/foreign language). Due to the differences between the Arabic and English article system, rest of the determiners and prepositions, which are very frequently used in English, such 
IJASOS- International E-Journal of Advances in Social Sciences, Vol. VI, Issue 18, December 2020

problems arise. This paper, mentions these problems, discusses, explains and analyzes them thoroughly.

\section{LITERATURE REVIEW}

Mother-tongue ("Mother Tongue," 2015) means one's native language or parent language whereas mothertongue interference refers to the influence of the native language of the learner on her/his acquisition of the target language. Notwithstanding, the target language is the language the learner is aiming to learn or (L2), in our case, it is the English language, while the mother-tongue is the Arabic language. ("Contrastive Analysis," 2015).

Teaching English as a second/foreign language, as with any language learning attempts is met with problems of mother-tongue interference which could lead to either positive transfer or negative transfer. Language transfer ("Language Transfer," 2019) refers to applying knowledge from one language to another language.

Positive transfer is when the mother-tongue helps in understanding and learning the target language due to similarities in both languages which assists in positively transferring or translating from the learners' first language into the target language. Negative transfer, on the other hand, is when the mother-tongue becomes a source of mistakes and errors due to the negative influence of the native language. In such circumstances, translating or transferring has a negative effect or influence. Usually, due to differences in both the Arabic and the English language, problems arise in the target language and in students' abilities to use good English in ESL/EFL classrooms and environments. Certain problems, due to L1 interference and negative transfer from the Arabic language, is found in learning English determiners, such as definite and indefinite articles, as well as correctly using prepositions in the English language. This is applicable in Contrastive analysis studies, which are concerned with the study of a pair of languages with the aim of discovering their structural similarities and differences. Contrastive Analysis is a method that was widely used with the aim of explaining why some features of a target language are more difficult to learn than others. (Mozlan, 2015, p7)

The Contrastive Analysis Hypothesis $(\mathrm{CAH})$ is grounded on the claim that the difficulty of second language learning could be foretold depending on the degree of difference between the learners' first and second language. (Eric, 2008, p1)

According to Lado's Linguistics across Cultures (1957) features of a target language that are similar to the learners' first language will be easy to learn. While, features of a target language that are different than the learners' first language will be difficult for the learner to acquire or learn. This is the basis of the Contrastive Analysis Hypothesis and contrastive analysis studies. (Mozlan, 2015, p8)

L1 Arabic learners of English tend to make repeatable mistakes and errors when learning to use many of the determiners that are frequently used in English. Specially, the definite and indefinite articles. Furthermore, prepositions which are also very often used in English are also faced with difficulties, repeatable mistakes and errors because of L1 Arabic interference. These mistakes and errors, as mentioned before, are attributed to the difference between the structural systems in both Arabic and English. These mistakes and errors are due to transfer from the learners' mother-tongue on the learners' target language. Mistakes and errors are a cause of negative transfer. However, sometimes, learners may come across positive transfer. As such:

Transfer can be of two types: positive transfer and negative transfer. The positive transfer refers to the process of using rules from L1 which facilitates or has a positive influence on learning L2. This transfer is mostly due to similarities between L1 and L2. In contrast, negative transfer is the transfer of rules from L1 which impedes or has harmful influence on the command of rules of L2. This is due to differences between L1 and L2. (Sabbah, 2015, p271)

The cause of errors can be explained by referring to language theories and learning theories. Among these theories are the Contrastive Analysis Theory and the Error Analysis Theory. Such theories assert that learners will tend to depend on and refer back to their native language when they encounter target language items that greatly differ with their mother-tongue. The second theory, which is present in contrastive studies, is used to explain learners' errors, known as "Error Analysis" and this theory studies learners' errors in the target language with the aim of recognizing the reasons behind such errors and their causes.

\section{METHODOLOGY}

A qualitative approach has been followed within this paper. Through the analysis and study of previous findings and research papers with regard to determiners, prepositions and negative transfer from the first language, data within this paper has been collected. Also, through the comparison of both the English 
IJASOS- International E-Journal of Advances in Social Sciences, Vol. VI, Issue 18, December 2020

language and the Arabic language, their structural systems and differences regarding this subject area, results within this paper have been reached.

\section{DISCUSSION AND RESULTS}

According to linguistic studies, earlier achieved, learning English language determiners, especially the definite and indefinite articles, along with learning the correct use of prepositions in English by students whose mother-tongue is Arabic is asserted to the significance of the Contrastive Analysis Hypothesis. I.e., due to the difference between the Arabic article system and the English article system, and due to the differences in the use of prepositions in both Arabic and English, many L1 Arabic learners of English encounter difficulties when trying to learn the correct use of articles and prepositions in English. The difficulty in learning English articles, for one reason, is tackled by L2 English learners, despite their backgrounds, is because either their native language has no article system or their native language has an article system that functions differently. According to the Arabic language, the concept of definiteness and indefiniteness is encoded differently in Arabic than in English. The English language system uses the definite article "the", the indefinite articles "a"/ "an", and the zero article " $\varnothing$ ". Nonetheless, the Arabic language uses the definite article "al" which is used almost in a similar way to the English definite article, because in Arabic, the notion of definiteness and indefiniteness is encoded differently than that in English. In Arabic, the definite article is "al"/ " ال ". I.e., the definite article has no equivalence in the Arabic language and, hence, there is no indefinite article in Arabic.

Contrastive Analysis and The Contrastive Analysis Hypothesis also explains the reason why prepositions are difficult and a major source of error for L1 Arabic students in ESL/EFL environments and classrooms.

Before moving more deeply, need arises to explain what is meant by prepositions. Prepositions are words that show the relationship between two things. So, for instance, the prepositions within the next examples are "behind, above, into, near" accordingly. These prepositions show the relationship between the falcon and the chimney as in "The falcon flew behind the chimney", "The falcon flew above the chimney", "The falcon flew into the chimney" or "the falcon flew near the chimney". ("Prepositions", 2019)

Prepositions, furthermore, include the following words such as: about, beside, inside, to above, besides, across, on, up, among, with, within, at, over, without, before, for, since, in through, into, etc. These are one word prepositions, whereas prepositions may consist of more than one word as in "along with", "in place of", "because of", "in spite of", "instead of", "except for", "in addition to", "out of", "in case of", "up to", "in front of." These are all types of the most common multiword prepositions. (Ibid)

Reasons behind the difficulty in learning English prepositions by non-natives, especially L1 Arabic students, is due to the confusion in when and where preposition may be used, which differs from the Arabic language. English prepositions appear all over. Prepositions may be placed in front of nouns (on Thursday), before gerund verbs (for speaking), as part of a phrasal verb (put up with) or after adjectives (interested in). Because there is no simple rule explaining when and how to use preposition, learners of English as a second/foreign language find them difficult to learn. Thus, L1 Arabic learners, in particular, refer back to the Arabic language in hope of better command of prepositions in English. Rules, similarly, can be overgeneralized. For example, telling a learner that by saying "I am happy for her" means that "I am pleased that she is happy" can lead a learner of English to overgeneralize this rule by mistakenly thinking that "I know she will be happy for this present" is correct English instead of "I know she will be happy with this present." These are some reasons of possible difficulty that Arabic native speakers may face when learning to use prepositions properly in English. However, due to difficulty in learning prepositions correctly, one of the most frequent sources of mistakes and errors is first language interference or Arabic mother-tongue interference which is a major cause of negative transfer. (Ibid)

This paper pinpoints Contrastive analysis studies and findings, regarding English determiners and prepositions, by clarifying how the differences between the Arabic and English languages, in concern to the article system and proper use of preposition, cause L1 Arabic learners of English to make mistakes or even errors in their English learning process. These mistakes or errors are involuntarily made by L1 Arabic learners of English due to the differences between the use of determiners, articles in particular, besides to prepositions also, in the two languages.

Errors and mistakes, that native Arabic speakers make, with regard to determiners: the definite/indefinite articles, in particular, could be made clear by the following examples: L1 Arabic students tend to say "University library is closed" rather than "The University library is closed" due to negative transfer from their mother-tongue. Because in Arabic, there is no use of the definite article, but a zero article is present, as in the sentence "مكتبة الجامعة مغلقة". In this sentence, the definite article should be used but is not, due to negative transfer and the differences in the use of determiners between English and Arabic, in this example. A further 
"بعمل أخي في مستشفى" mistake students commit, regarding, articles and negative transfer, could be exemplified in which is often negatively transferred into "My brother works in hospital" rather than "My brother works in a hospital", which is the correct form. Here, there is no use of articles, negatively affected by transfer from the first language. The correct form should contain the indefinite article "a" instead. A third example could be given, in the sentence "wich is usually negatively transferred into "I live in the Iraq" and not "I live in Iraq". Thus, negative transfer from the native-language is usually because of difficulties faced by students in their ability to command proper use of determiners, which is often made by differences in the structural system of both English and Arabic. (Sabbah, 2015, p272)

Moreover, according to research studies, learning to use prepositions is one of the most difficult aspects of the English language, for L1 Arabic students to learn. Due to variety between the two languages regarding preposition rules and usage, correct rule command of preposition use in English is seen to be demanding for Arabic natives attempting to learn English. However, the extent of difficulty regarding accurate preposition use that learners of English encounter is not the same. I.e., some prepositions are found more difficult to learn than others. (Alsharafi, 2017, p2)

Learning English prepositions by students whose mother-tongue is Arabic is asserted to the significance of the Contrastive Analysis Hypothesis. This research paper supports these findings. Due to the difference between what, when, how and why to use prepositions in the Arabic language and that of the English preposition system, many Arabic L1 learners of English encounter difficulties when trying to learn the correct use of prepositions in English language. The difficulty in learning English prepositions, that Arabic first language learners of English, face is mainly in areas where the prepositional system functions differently in L2 (English) than that of the L1 (Arabic). This is linguistically known as the effect of first language (Arabic) interference, and negative transfer from the mother-tongue or native language.

As stated, mistakes Arabic L1 learners of English as a second/ foreign language make, are in some sense similar to one another and are not arbitrary or random. For instance, students of English language, from an Arabic L1 background, usually say "part from the plan" when using the preposition "from" and not "part of the plan". Another mistake learners make when using prepositions is "I thank may friend on her advice" which is incorrect and should be actually "I thank my friend for her advice".(Alsharafi, 2017, p3)

Moreover, learners of English in ESL/EFL, by negatively transferring from their first language (Arabic) and because of native language interference may give an example which is very commonly repeated by EFL/ESL students "They told him on everything", which should actually be "I told him about everything". These incorrect examples are made because of transfer from the mother-tongue, which in this situation harmful, not helpful. (lbid)

\section{CONCLUSIONS}

This paper concludes that learning English determiners, such as the definite and indefinite articles as well as learning proper use of preposition in the English language by students whose mother-tongue is Arabic emphasizes the importance of Contrastive Analysis studies. In this paper, the need to put focus on The Contrastive Analysis Hypothesis and Error Analysis is highlighted. Due to the fact that Arabic L1 learners of English as a second/foreign language find difficulty when attempting to use English is attributed to negative transfer from the mother-tongue. The source of many repeatable mistakes and common errors is based on the degree of difference between the Arabic structural system and the English structural system.

The difficulty in learning English determiners and prepositions by Arabic L1 speakers is mostly because their native language's influence on learners and on their ability to learn determiners and prepositions, which function differently in their Arabic language than its function in English. This, in turn, puts focus on the influence of negative transfer and need to be aware of its effects on language learning.

Therefore, teachers of English as a second/foreign language should become aware of these language issues, consider the influence of mother-tongue interference and the effects of negative transfer from Arabic on learning English as a second/foreign language. Teachers should become aware of such matters and clarify them to their students, all in hope of better language proficiency, better English language teaching, English language learning and better success and achievement for both teachers and students. By knowledge of the most common problems, English language learners face due to mother-tongue interference and negative transfer from the learners' first language, ESL/EFL students and learners of English may overcome many repeated mistakes and errors. This will certainly lead to better English language teaching and learning, especially for those of an Arabic mother- tongue. 


\section{REFERENCE LIST}

Al-Lami, M. (2006). Assessing EFL Students' Cultural Awareness of the English Language. Unpublished M.A. Dissertation. University of Baghdad, Iraq.

Alsharafi, S. (2017). Contrastive analysis between English and Arabic prepositions. Retrieved from: https://www.academia.edu/5277824/Contrastive analysis between English and Arabic prepositio ns $(10 / 5 / 2019)$.

Contrastive Analysis (n.d.). Retrieved from: https://en.wikipedia.org/wiki/Contrastive analysis (17/5/2019).

Determiners (n.d.). Retrieved from: http://cbse.nic.in/publications/interact in english wb ix/UNIT-2.PDF $(17 / 5 / 2019)$.

Contrastive Analysis Hypothesis (2008). Retrieved from: http://embruner.blogspot.com/2008/04/contrastiveanalysis-hypothesis.html (10/5/2019).

Hassan, M. (2011). Acquisition of English Articles by L1 Arabic Speakers. University Putra Malaysia, Malaysia. Retrieved from: http://psasir.upm.edu.my/20076/1/FBMK 201124 ir.pdf

Lado, R. (1957). Linguistics Across Cultures. Michigan: University of Michigan Press. Language transfer. (n.d.). Retrieved from: https://en.wikipedia.org/wiki/Language transfer (2/5/2019).

Mazlan, A. (2015). Contrastive Analysis Theory. Retrieved from: http://ar.scribd.com/doc/129396815/Contrastive-Analysis-Theory\# (2/5/2019).

Mother-Tongue. (2017). Retrieved from: http://dictionary.cambridge.org/us/dictionary/english/mother-tongue $(6 / 6 / 2019)$

Mother Tongue. (2015). Retrieved from: http://www.thefreedictionary.com/mother+tongue (5/6/2019)

Prepositions. (n.d.). Retrieved from: https://www.nova.edu/tutoring-testing/studyresources/forms/prepositions.pdf (7/4/2019).

Sabbah, S. (2015). Negative Transfer: Arabic Language Interference to English Learning. Arab World English Journal. Retrieved from:

http://www.academia.edu/12680728/Negative Transfer Arabic Language Interference to Learning English (4/6/2019). 